\title{
ループ型熱音響音波発生機の特性
}

\author{
畠沢 政保 ${ }^{*}$ ， 野中健太郎*
}

*日本大学短期大学部 千葉県船橋市習志野台 7-24-1 ( ${ }^{\dagger}$ E-mail: hatazawa @eme.cst.nihon-u.ac.jp)

**（株）本田技術研究所杤木研究所 杤木県芳賀郡芳賀町下高根沢 4630

( 2000 年 12 月 15 日受理 )

\section{Characteristics of a Loop-type Thermoacoustic Sound Wave Generator}

\author{
Masayasu HATAZAWA and Kentarou NONAKA \\ Junior College of Nihon University, 7-24-1 Narashinodai, Funabashi-shi, Chiba 274-8501 \\ Honda R\&D Co. Ltd., 4630 Shimotakanezawa, Haga-machi, Haga-gun, Tochigi 321-3393
}

(Received December 15, 2000)

\begin{abstract}
Synopsis: The characteristics of a new loop-type thermoacoustic sound wave generator, in which two closed-end connected-type generators are connected to each other at the open ends by four bent tubes and sealed hermetically, are described. It has been reported that two types of sound wave generators, in which two identically shaped systems are connected to each other at either the open ends or the closed ends, can operate stably. In the new loop-type sound wave generator, which has the benefits of the above-mentioned types of sound wave generators, the pressure, velocity amplitude, acoustic intensity, and heat transferred by sound waves are greater than those of the other connected-type ones. And harmonics in pressure signals and no harmonics in velocity signals are observed at the connected part. An optimum theoretical sound wave frequency of $100 \mathrm{~Hz}$ is also confirmed for this type of sound wave generator.

Key words: thermoacoustic phenomena, sound wave generator, velocity amplitude, pressure amplitude, heat transfer
\end{abstract}

\section{1. 緒言}

可動部分が全く無く, 熱から仕事（音波）へのエネ ルギ変換が直接できることから, 熱音響現象 1)が注目 されており, 近年各機関や企業で研究が盛んに行われ ている. また, 熱音響現象を利用した冷凍機 ${ }^{2)}$, パイ

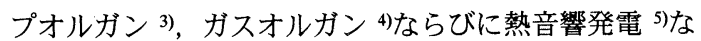
どの報告がされているものの, その変換効率が依然低 いため，実用化にほど遠いのが現状である.

以上の背景から，筆者らは，熱音響現象を利用する 機器の開発 6)を進めているが, それと並行して, 熱か ら仕事へのエネルギ変換効率の向上を目指して, 上記 機器において重要な役割を果たす熱音響音波発生機の 開発 6)を行っている.

その一環として, 従来, 単独で用いられていた熱音
響音波発生機（以降，音波発生機という） 2 機の閉口 端部の蓋を取り除き閉口端同志で結合するあるいは開 口端同志で結合する突き合わせ型熱音響音波発生機 7) を提案し, 性能を確認した. その結果, 特別な制御を しなくても，2 機の音波発生機を閉口端部の蓋を取り 除き閉口端同志で結合させる（以降，閉口端結合とい う）と, 圧力・速度振幅が共に単独動作の場合とほぼ 等しく，音波による熱輸送量もほとんど変わらない， また，結合部を境に等距離離れた位置における各号機 の圧力変動の位相が自然と同期する. 一方, 2 機の音 波発生機を開口端同志で結合させる（以降，開口端結 合という）と, 圧力・速度振幅が共に単独動作に比べ て著しく増加し，音波による熱輸送量も大幅に増大す る. かつ結合部を境に等距離離れた位置における各号 機の圧力変動の位相が自動的に反転する極めて興味深 
い現象が確認できた 7).

上記の開口端同志および閉口端同志を結合した両機 の特徵いずれも熱音響現象を利用する機器の性能を向 上させるのに大きく寄与すると考えられることから， ここでは双方の結合機の長所を充分に反映させるべく, 2 組の閉口端結合機をさらに開口端同志で結合し, か つ密閉したループ型熱音響音波発生機を開発し, 充分 に動作することを確認した ${ }^{8)}$. また, 音波発生機を単 独で, あるいは 2 機を閉口端同志および開口端同志で 結合して動作させたいずれの場合に比べても, ループ 型音波発生機の性能が飛躍的に向上することを確認し た.さらに, 本研究に採用している形式の音波発生機 では, 最適な発生音波の理論周波数が $100 \mathrm{~Hz}$ であるこ とを再確認したので, それらの報告をする.

\section{2. 実験装置および実験方法}

Fig. 1 に音波発生機を示す. 同一仕様の音波発生機を 4 機（以降, 1 号機, 2 号機, 3 号機, 4 号機という) 製作し, 実験条件に応じて, 適宜, 音波発生機を各々 単独で，あるいは突き合わせ型では 2 機，またループ 型では 4 機組み合わせて使用した. 個々の音波発生機 は共鳴管, スタック, 高温・低温熱交換器からなる. 共鳴管全長 $L$ （基本周波数の音波が発生する時, 共鳴 管の長さは発生音波の $1 / 4$ 波長に相当する）は設定し ようとする発生音波の理論周波数 $f_{\mathrm{TH}}$ によって異なるが, ここでは共鳴管内の空気の温度を $20{ }^{\circ} \mathrm{C}$ 仮定したと きに $f_{\mathrm{TH}}=75 \mathrm{~Hz}$ となるように $1,130 \mathrm{~mm}$ とした. しかし, 音波発生機を単独あるいは各結合して動作させたいず れの場合も, 共鳴管内では気体温度が仮定した $20{ }^{\circ} \mathrm{C}$ より高く, 空気の音速が速いため, 奏際に発生する音 波の周波数は $f_{\mathrm{TH}}$ より約 $7 \%$ 高い $80 \mathrm{~Hz}$ を得ている. な お, 共鳴管の高温部には内径 $30 \mathrm{~mm}$, 肉厚 $1 \mathrm{~mm}$ の SUS304 製ステンレス管を, また, 共鳴管内各部の温度, 速度, 圧力の測定および流れの観察を容易にするため に, 低温部には内径 $32 \mathrm{~mm}$, 肉厚 $4 \mathrm{~mm}$ の透明なアク リル管を使用した. さらに, スタックには内径 $1.6 \mathrm{~mm}$, 肉厚 $0.2 \mathrm{~mm}$, 長さ $80 \mathrm{~mm}$ の SUS304 製ステンレス管を 180 本束ねたものを使用した.

高温熱交換器は約 $800{ }^{\circ} \mathrm{C}$ もの高温に熱せられるため, 酸化を防ぐ上から, ニッケル製とし，その外周に外径 $1.6 \mathrm{~mm}$, 長さ $1.88 \mathrm{~m}$, 発熱量 $500 \mathrm{~W}$ のシース型ヒータ を巻き直流電源（6 A, $110 \mathrm{~V})$ により加熱した．低温 熱交換器は全て銅製であり，外周部にはんだ付けした 銅管内に水を流して冷却した，両熱交換器には，作動 気体との熱の授受を効率良く行うために, 中央部に直

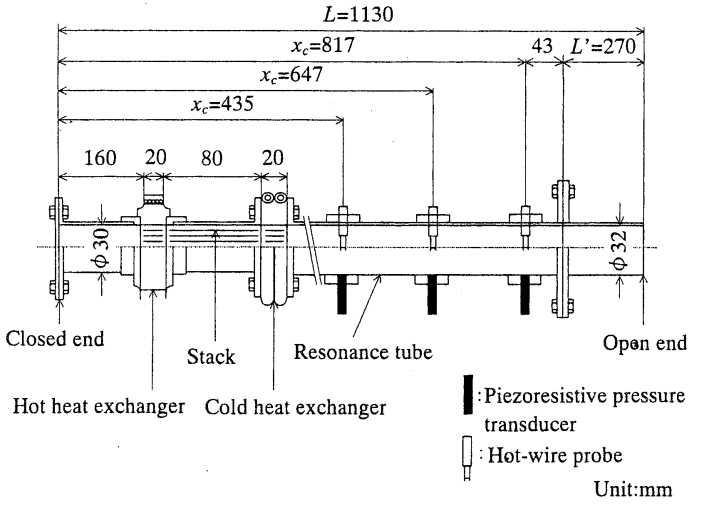

Fig. 1 Single-type thermoacoustic sound wave generator.

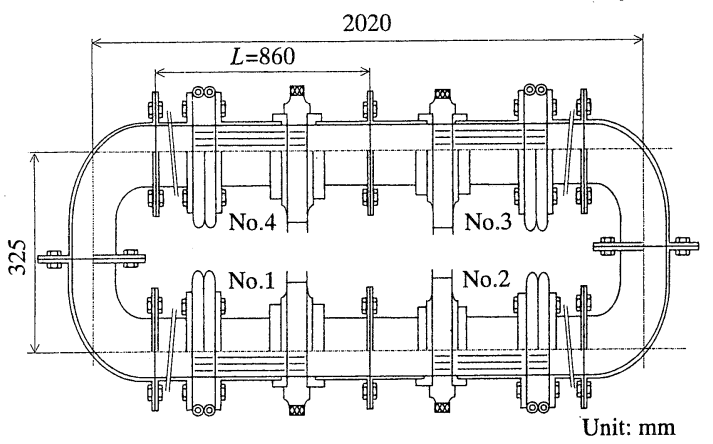

Fig. 2 Loop-type thermoacoustic sound wave generator.

径 $3 \mathrm{~mm}$ の孔が 55 個開けられており, 厚さは共に $20 \mathrm{~mm}$ である。

Fig. 2 に新しく開発したループ型熱音響音波発生機を 示す. 同仕様の音波発生機を 4 機使用しており, 1,2 号機および 3,4 号機を閉口端同志で結合させ, さらに 1, 4 号機および 2, 3 号機の開口端同志を中心円周長 さ $270 \mathrm{~mm}$, 曲率半径 $100 \mathrm{~mm}$, 内径 $32 \mathrm{~mm}$ の SUS304 製ステンレスベンド管を用いてループ状に接続し, 共 鳴管を密閉した. なお, 作動流体には大気圧の下の空 気を用いた. 高温・低温熱交換器, スタックおよび共 鳴管内各位置における温度はシース外径 $0.3 \mathrm{~mm}$ の $\mathrm{K}$ 型熱電対 (助川電機) で, また, 低温熱交換器の出入 口水温はシース外径 $3.2 \mathrm{~mm}$ の白金測温抵抗体（助川電 機）で測定し，レコーダに，またスキャナを介してコ ンピュータに記録した.

さらに，同じ位置における管中心部の速度を I 型プ ローブを用いて定温度型熱線風速計（日本カノマック ス 1010）で，また管壁の圧力を半導体圧力センサ（エ 

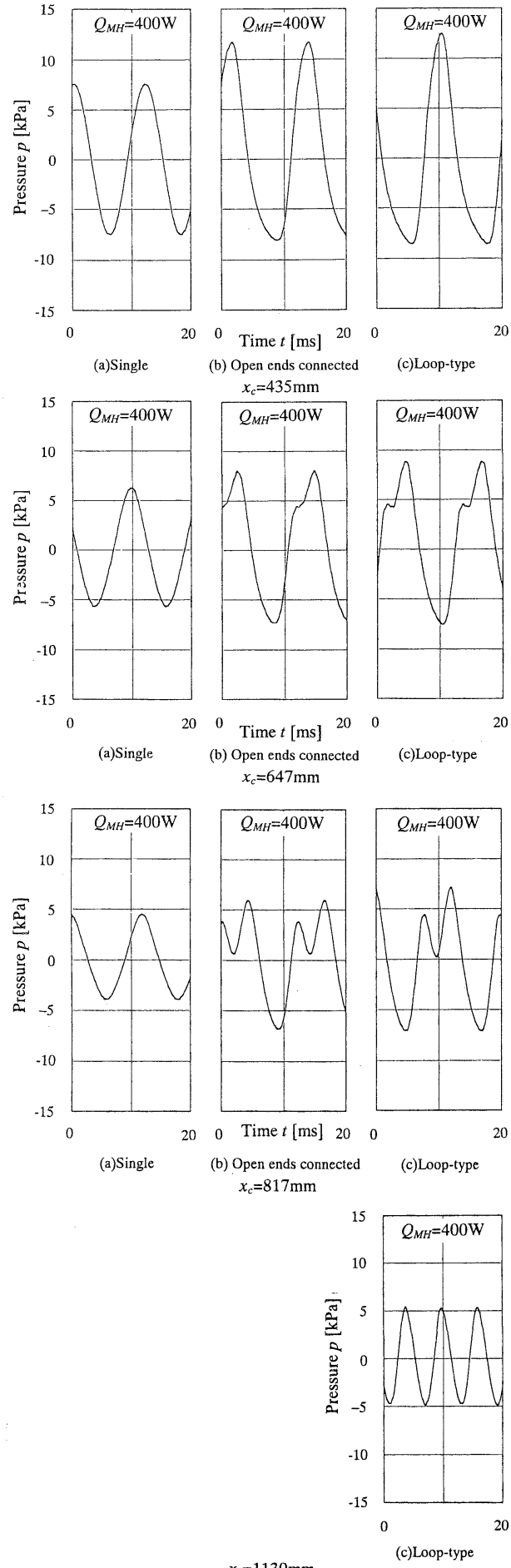

Fig. 3 Pressure signals in the resonance tube.
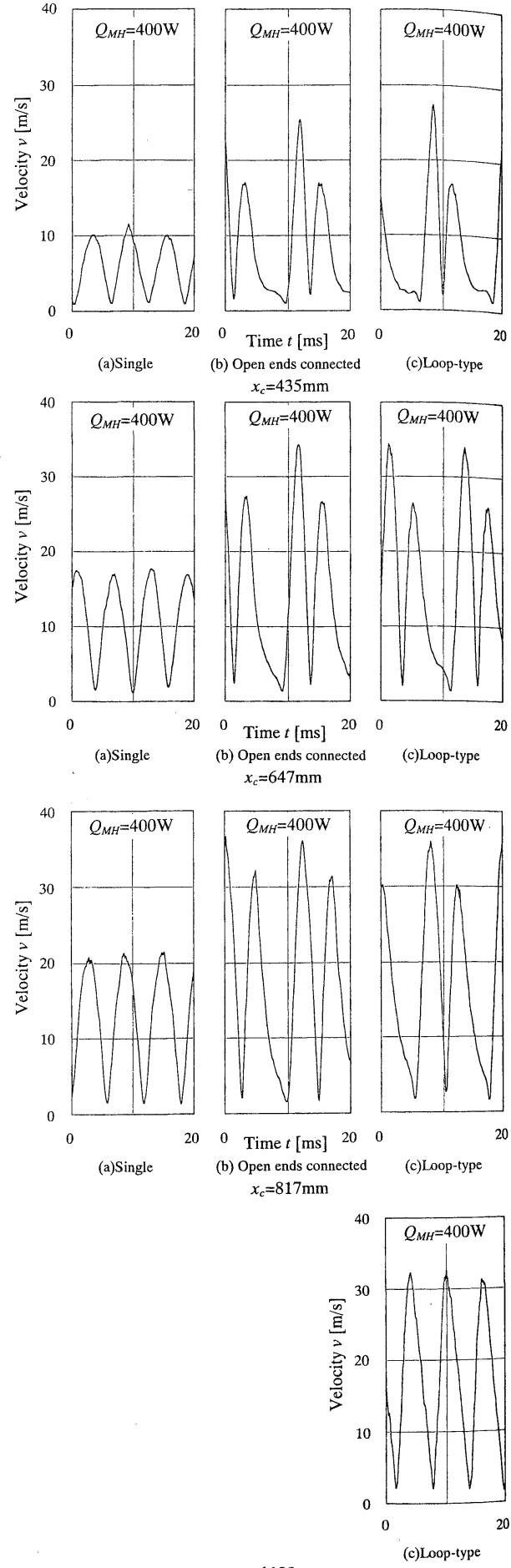

Fig. 4 Velocity signals in the resonance tube. 
ンテブコ 8501C-15）で同時に検出し，取り込夕時間 100 $\mu \mathrm{sec}$ で $\mathrm{AD}$ 変換して, パソコンで処理した後, 適宜プ リンタに出力した。

\section{3. 実験結果および検討}

\section{1 ループ型音波発生機の特性}

\subsection{1 速度および圧力の波形}

Fig 3, 4 は $f_{\mathrm{TH}}=75 \mathrm{~Hz}$, 熱入力 $Q_{\mathrm{MH}}=400 \mathrm{~W}$ の場合, 波発生機を単独動作，開口端結合およびループ型で 的作させたときの共鳴管内の各位置において同時測定 した圧力，速度波形を示す．なお，単独動作と閉口端 合機では閉口端から等しい距離離れた位置における 化力，速度の振幅および波形がほとんど変わらないた め、ここでは閉口端結合機の結果を割愛した。単独動 作に比べ，開口端結合機およびループ型の圧力・速度 の両波形が大きく異なっている.

単独動作では, 閉口端からの距離 $x_{\mathrm{c}}$ の違いにかかわ らず, 圧力と速度の位相が約 90 度ずれ，また，双方の 形が正弦波状を呈している。しかし，共鳴管内に空 気が密閉されている開口端結合機およびループ型では, $x_{\mathrm{c}}$ の各位置における圧力・速度の波形は共に特異であ り，正弦波とかけ離れた形になっている．さらに，共 管結合部に近付くにつれて, 圧力波形は分波してお り. 速度波形の 2 倍の周波数成分が現れている. 特に, ループ型では, $x_{\mathrm{c}}=1,130 \mathrm{~mm}$ (開口端同志の結合部) の 位国において圧力波形が発生音波周波数の 2 倍に分波 しており，きれいな正弦波形をしている，一方，速度 振幅は各結合機共に $x_{\mathrm{c}}=435 \mathrm{~mm}$ で最も小さく, $x_{\mathrm{c}}$ の増 加と共にその振幅は大きくなる. さらに， $x_{\mathrm{c}}=435 \mathrm{~mm}$ において順流，逆流（閉口端から開口端側への流れを 梳流，その逆方向の流れを逆流という）の速度振幅の 差が最も大きいが， $x_{\mathrm{c}}$ の増加と共にその差は小さくな ク、ループ型の場合, $x_{\mathrm{c}}=1,130 \mathrm{~mm}$ では順流・逆流の 速度振幅にほとんど差が見られない，さらに，速度波 形に発生音波の基本周波数成分のみが見られる.一方,

壬力波形には発生音波の 2 倍の周波数成分が見られる 用味深い結果が得られた。

以上のことは，2 機の音波発生機を開口端同志で結 合させると, 結合部付近で特異な現象が生じているこ とを示唆している. したがって今後, 圧力・速度をよ り群紐に測定して, 共鳴管内の流れの機構（振動流） を解明する必要がある。

\section{1 .2 共鳴管内の気体の運動}

Fig. 5 は $Q_{\mathrm{MH}}=400 \mathrm{~W}$ で, 2 機の音波発生機を各々単 蝴に,また開口端同志および閉口端同志で結合させて

Vol. 36 No. 4 (2001)

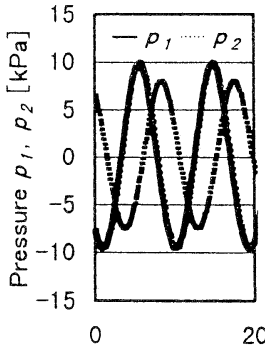

(a) Single

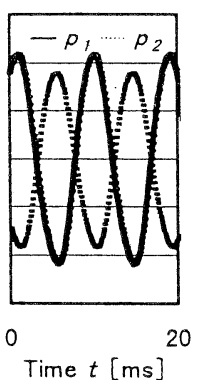

(b) Open ends connected

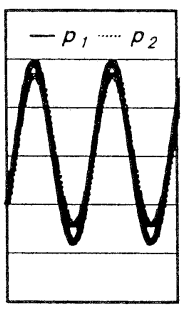

20 connected

Fig. 5 Phase difference in pressure signals.

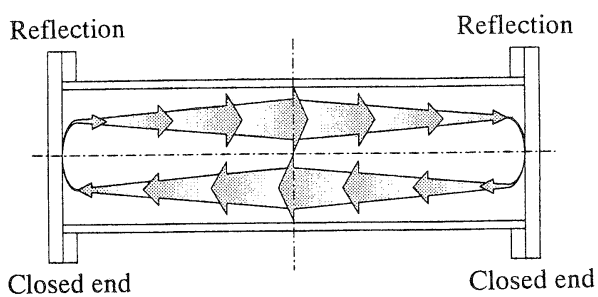

(a) Open-end connected type.

Imaginary reflection surface

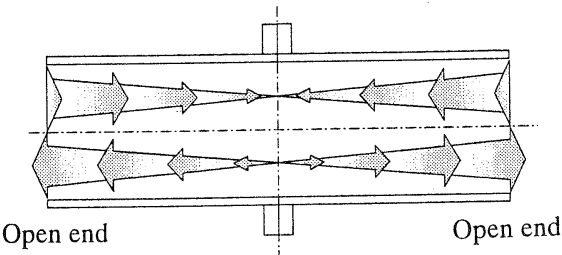

(b) Closed-end connected type.

Fig. 6 Conceptual diagram of flow in the resonance tube.

動作させた場合の閉口端あるいは閉口端結合部から 435 $\mathrm{mm}$ 離れた位置における各号機の圧力波形を示す》。

2 機の音波発生機が各々単独で動作する場合，双方 の発生周波数がほぼ等しいものの, 双方の位相には関 連性が無い。一方, 開口端結合機では, 結合部より等 距離離れた各号機の圧力振幅が単独動作に比べて増大 し，かつ双方の圧力波形が反転しており，位相が 180 度ずれている，しかし，閉口端結合機では，両機の圧 力波形が同位相になっており，多少の差は見られるも のの双方の圧力振幅值がほとんど等しくなっている.

以上のことから，突き合わせ型音波発生機の共鳴管 内における作動流体は Fig. 6 (a)，(b)に示すように動作 していると考えられる，なお，図中の矢印の大きさは 
速度振幅の大きさを模式的に表す。開口端結合機では, 作動流体は両閉口端で交互に反射され共鳴管内で単純 に往復運動している。しかし，閉口端結合機では，2 機の音波発生機が閉口端において蓋が取り除かれて結 合されており，共鳴管内が貫通しているにもかかわら ず，両音波発生機の結合部にあたかも壁があり，そこ で各号機内に発生する音波が反射されているような流 れになっていると考えられる.

ループ型音波発生機は, 2 機の音波発生機を開口端 同志で結合ならびに閉口端同志で結合して動作させた 両方の場合の特徵を有しており，さらに，Fig. 3，4に 見られるように，閉口端あるいは閉口端結合部より等 距離離れた位置において各号機の圧力と速度が開口端 結合機と同様の変化をしていることから，密閉された 共鳴管内では作動気体が上記両結合機の共鳴管内の流 れと類似の運動をしていると思われる.

\subsection{3 熱音響音波発生機の性能評価}

結合の違いによる音波発生機の性能向上を評価する 際に, 本研究では, 圧力振幅, 速度振幅および音波に よって運ばれる熱量，さらに次に示す音響の強さ 9,10)を 採用する。

一方が閉じ，もう一方が開放している管の中に定在 波が存在すると仮定すれば, 閉口端からの距離 $x_{\mathrm{c}}$ にお ける共鳴管内の圧力および速度振幅の変化は

$$
\begin{aligned}
P_{a} & =P_{a \max } \cos \frac{2 \pi x_{c}}{4 L} \\
V_{a} & =V_{a \max } \sin \frac{2 \pi x_{c}}{4 L}
\end{aligned}
$$

で表される. また圧力と速度の時間変化はそれぞれ

$$
\begin{aligned}
& p=P_{a} \cos \omega t=P_{a \max } \cos \frac{2 \pi x_{c}}{4 L} \cos \omega t \\
& v=V_{a} \sin \omega t=V_{a \max } \sin \frac{2 \pi x_{c}}{4 L} \sin \omega t
\end{aligned}
$$

で表される．したがって閉口端から $x_{\mathrm{c}}$ における共鳴管 内の音響の強さ $\left.{ }^{9,10}\right)$ は式(5)で表すことができる.

$$
\begin{aligned}
p v & =\frac{1}{2} P_{a} V_{a} \sin 2 \omega t=\frac{1}{4} P_{a \max } V_{a \max } \sin \frac{\pi x_{c}}{L} \sin 2 \omega t \\
& =\frac{1}{4} \frac{P_{a \max }{ }^{2}}{\rho c} \sin \frac{\pi x_{c}}{L} \sin 2 \omega t
\end{aligned}
$$

よって,ここでは閉口端より任意の距離 $x_{\mathrm{c}}$ における共 鳴管内の発生音波の音響強さとして, 圧力振幅と速度 振幅の積よりなる $1 / 2 P_{a} V_{a}$ を採用する. また, 音響の 強さは, $2 \omega t=(2 n+1 / 2) \pi(n$ は正の整数である）かつ 共鳴管長さのちょうど半分の位置 $x_{\mathrm{c}}=L / 2$ で最大とな
り, $1 / 4 P_{a \max } V_{a \max }$ もしくは $P_{a \max }^{2} /(4 \rho c)$ となる. した がってここではそれらの值も合わせて採用する.

\section{1 .4 圧力および速度振幅の分布}

本研究では 4 機の音波発生機を同じ仕様で製作した にもかかわらず，各号機の性能に僅かな差が見られる ため,ここでは音波発生機を単独ならびに各結合して 動作させたいずれの場合も同じ号機で各性能を評価し ている.

Fig. 7 は音波発生機を単独, 開口端結合, 閉口端結合 およびループ型で動作させた場合（いずれの場合も発 生音波の理論周波数は $f_{\mathrm{TH}}=75 \mathrm{~Hz}$ である）の閉口端か らの距離 $x_{\mathrm{c}}=435 \mathrm{~mm}$ における熱入力 $Q_{\mathrm{MH}}$ の変化に伴う 圧力振幅 $P_{a}$ の変化を示す. なお, ここで圧力振幅は Fig. 3 に示す各位置における圧力変動より, その最大値と して求めた. 結合の違いによる差は明らかであり, 各 熱入力においてループ型音波発生機の圧力振幅が他の 結合機に比べて際だって大きい. $Q_{\mathrm{MH}}=400 \mathrm{~W}$ の場合, 単独動作と同程度の閉口端結合機に比較して約 $2 \mathrm{kPa}$,

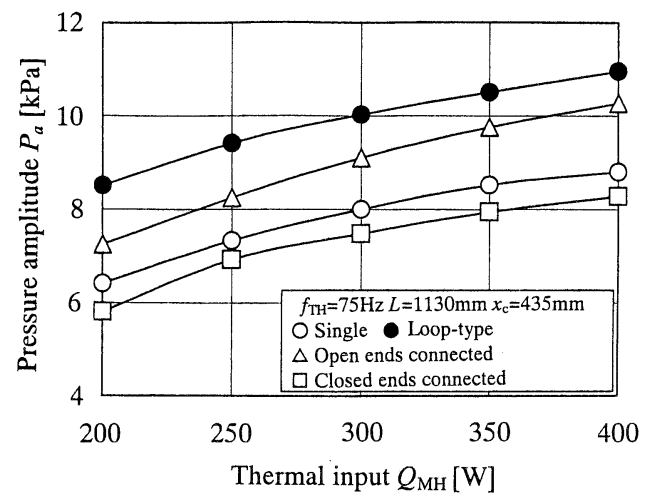

Fig. 7 Change in pressure amplitude.

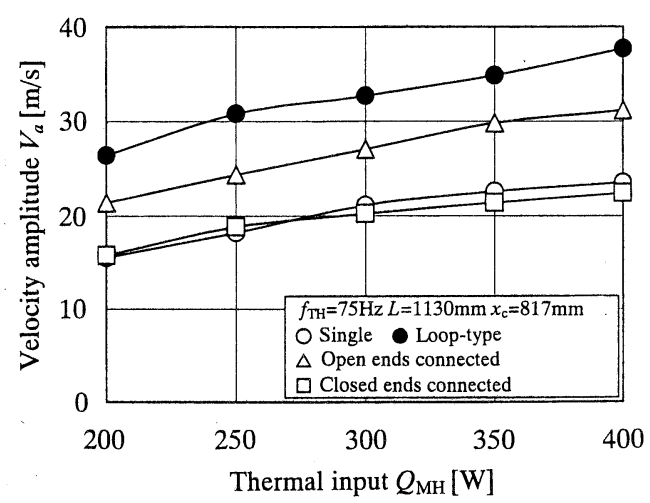

Fig. 8 Change in velocity amplitude. 


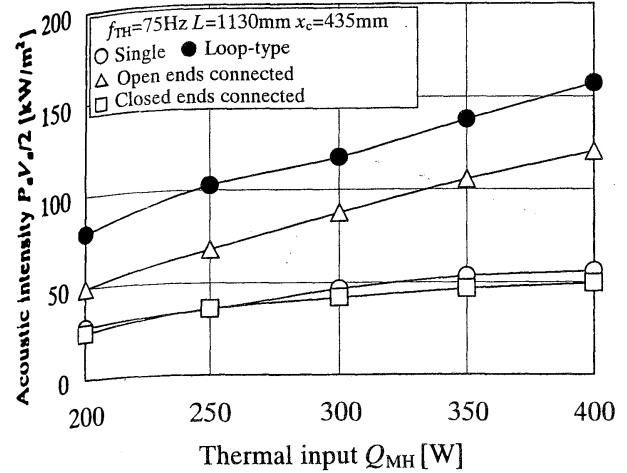

Fig. 9 Change in acoustic intensity.

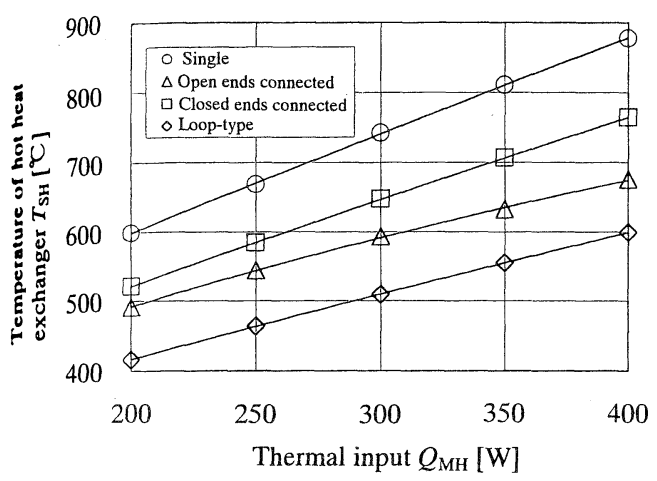

Fig. 10 Change in temperature of hot heat exchanger.

$25 \%$ 増加しており, また, 開口端結合機に比べても 为 $1 \mathrm{kPa}, 10 \%$ 増加している.

Fig. 8 は音波発生機を単独あるいは各結合して動作さ 世た場合の, 熱入力 $Q_{\mathrm{MH}}$ の変化に伴う 1 号機の $x_{\mathrm{c}}=817$ m n における速度振幅 $V_{a}$ の変化を示す. なお，ここで 速度振幅は Fig. 4 に示す各位置における速度変動より,

その最大値として求めた. 圧力振幅の結果と同様に 4 の音波発生機をループ状に結合させた効果は顕著で あり, 熱入力 $Q_{\mathrm{MH}}=400 \mathrm{~W}$ のとき, 単独動作および閉 口端結合機と比較して速度振幅が約 $60 \%$ 以上も大幅に 覞加しており，さらに，開口端結合機に比べても約 6.5 m/s, 20\%増加している。

Fig. 9 は, $f_{\mathrm{TH}}=75 \mathrm{~Hz}, x_{\mathrm{c}}=435 \mathrm{~mm}$ における音波発生 維を動作および各結合させ動作させた場合の音響 強さ $1 / 2 P_{a} V_{a}$ の変化を示す. 単独動作および各結合機 の音響強さは熱入力 $Q_{\mathrm{MH}}$ の増加とともに増加する．ま た，各熱入力において音響強さは単独動作に比べて， 朋口端結合機では同等であり, 開口端結合機では 2 倍 以上,さらにループ型では 2.8 倍以上に増加している。

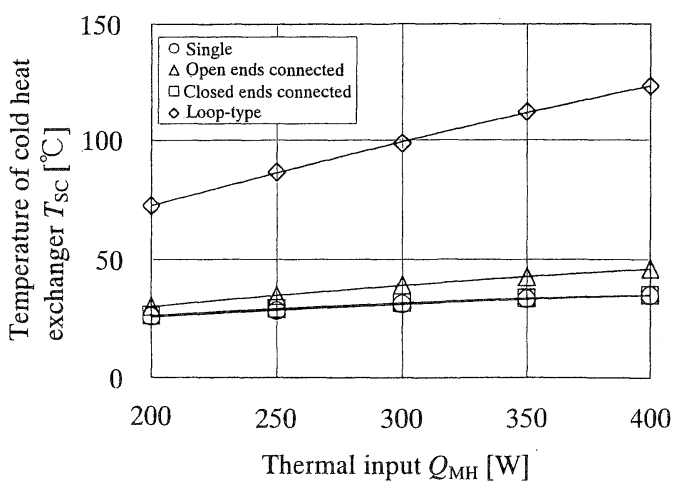

Fig. 11 Change in temperature of cold heat exchanger.

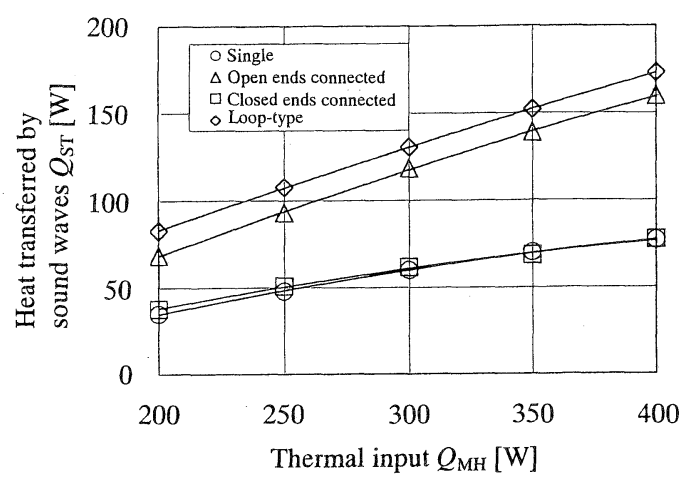

Fig. 12 Change in heat transferred by sound waves.

以上に述べたように，2 組の閉口端結合機をさらに 開口端同志で結合したループ型音波発生機では，単独 動作および開口端結合機に比べて各性能が際だって向 上している，その原因として，ループ型では，共鳴管 の結合部に近付くにつれて，各号機自身から発生する 音波と他の号機から発生する音波とその閉口端で反射 される音波との間の相互干渉がより一層增大する。 そ の結果, 作動流体の押し込み効果がより一層顕著にな り，速度・圧力振幅および音響の強さが共に増加する ためと考えられる.

なお，単独動作および各結合において圧力および速 度変動の波形より求められた発生音波の周波数の実測 值は $80 \mathrm{~Hz}$ であり，理論值 $75 \mathrm{~Hz}$ よりも約 $7 \%$ 高い值を 示している. その理由として, 理論発生周波数は $20{ }^{\circ} \mathrm{C}$, 大気圧の下の空気で算出しているが, 単独および各結 合で動作する場合，共鳴管内の気体温度が上昇し，音 速が増加する. その結果, 実測値が理論値よりも高い と思われる。 


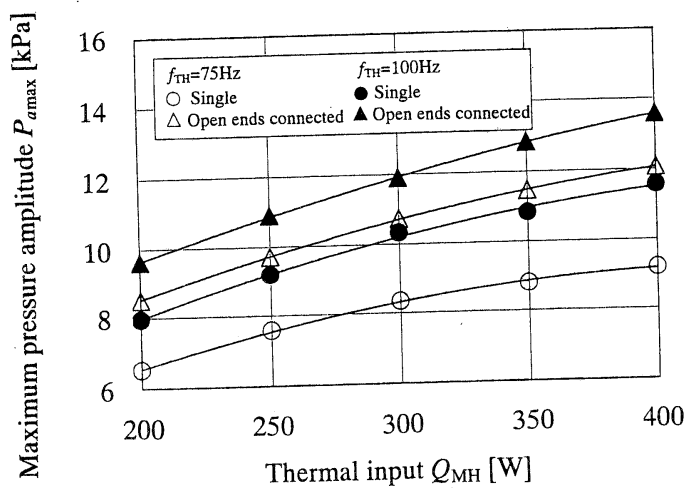

Fig. 13 Change in maximum pressure amplitude.

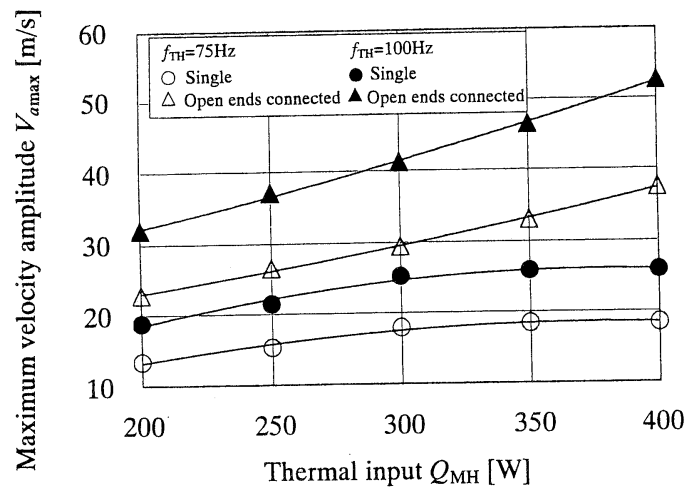

Fig. 14 Change in maximum velocity amplitude.

\subsection{5 高温・低温熱交換器の温度および音波による 熱輸送量の変化}

Fig. 10, 11 は結合の変化に伴う高温・低温熱交換器 の温度 $T_{\mathrm{SH}}, T_{\mathrm{SC}}$ の変化を示す. $Q_{\mathrm{MH}}=400 \mathrm{~W}$ では, 高温 熱交換器の温度はループ型が最も低く, 開口端結合機 より約 $70{ }^{\circ} \mathrm{C}$, 単独動作に比べ約 $280{ }^{\circ} \mathrm{C}$ も低くなる. また, 低温熱交換器の温度はループ型が最も高く, 開 口端結合機に比べ約 $80{ }^{\circ} \mathrm{C}$, 単独動作に比べると約 $90{ }^{\circ} \mathrm{C}$ も上昇する. すなわち, 高温熱交換器から低温熱 交換器へ音波によってより多くの熱が運ばれ，その結 果, 高温熱交換器の温度は低下し, 逆に低温熱交換器 の温度が上昇するものと考えられる.

また, 音波による熱輸送量 $Q_{\mathrm{ST}}$ は, 低温熱交換器の 冷却水の出入口温度差と水量より求めた排熱量 $Q_{\mathrm{sw}}$ よ りスタックを伝わる伝熱量 $Q_{\mathrm{SO}}$ （計算値）を差し引い たものであり, 式(6)で求められる.

$$
Q_{\mathrm{ST}}=Q_{\mathrm{SW}}-Q_{\mathrm{SQ}}
$$

Fig. 12 は結合の違いによる音波による熱輸送量 $Q_{\mathrm{ST}}$ の変化を示す. 圧力・速度振幅の結果之同様に $Q_{\mathrm{MH}}=400$ $\mathrm{W}$ のとき,ループ型音波発生機における $Q_{\mathrm{ST}}$ が開口端

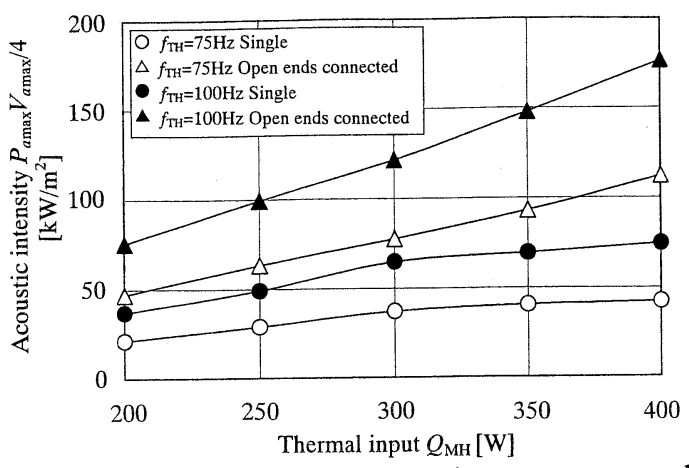

(a) Acoustic intensity based on maximum pressure and velocity amplitude.

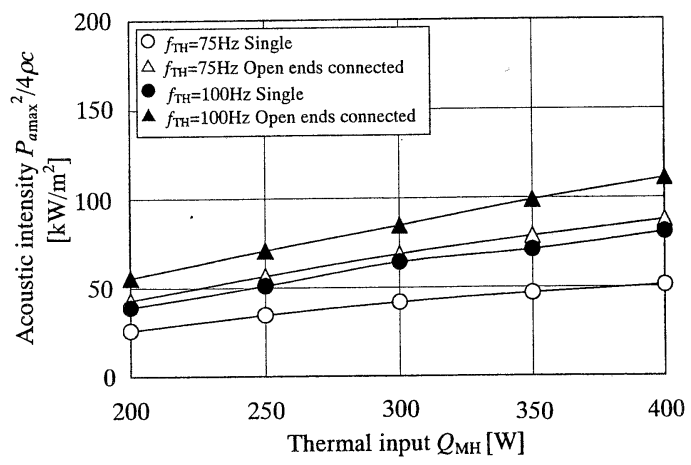

(b) Acoustic intensity based on maximum pressure amplitude and acoustic impedance.

Fig. 15 Change in acoustic intensity at different theoretical sound wave frequency.

結合機に比べ約 $10 \%$, 閉口端結合機に比べ約 $90 \mathrm{~W}$ も 増大する.

以上のことからループ型音波発生機では単独動作に 比べ各性能が優れている開口端結合機に比べてもなお 圧力・速度両振幅, 音響の強さおよび音波による熱輸 送量が大幅に増大していることから，さらなる熱音響 機器の性能向上が期待できる. よって, 今後, より多 数の音波発生機を組み合わせた螺旋型音波発生機等の 開発も考えられる.

\section{2 音波発生機の性能に及ぼす発生音波周波数の \\ 影響}

是永と畠沢は本研究に採用した形式の音波発生機に おいて, 共鳴管の長さを変えることで理論周波数を $f_{\mathrm{TH}}=$ 50 125 Hz に, また熱入力を 200 300 W の範囲で変え て共鳴管内各位置において I プローブおよび定温度型 熱線風速計を用いて管中央部の軸方向速度変動の測定 を行い, 最適な発生音波周波数 $f_{\mathrm{op}}$ が $75 \mathrm{~Hz}$ あるいは 100 


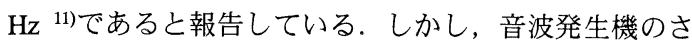
らなる性能向上を目指す上でも, $f_{\mathrm{op}}$ を再確認する必要 がある.よって, ここでは, 最大圧力振幅, 最大速度 振幅および音響の強さを採用して, 別に行った実験結 果から $f_{\mathrm{op}}$ を再確認する. なお最大圧力振幅 $P_{a \max }$ は $x_{\mathrm{c}}=$ $435 \mathrm{~mm}$ における圧力振幅 $P_{a}$ を式(1)に代入して求め, 最大速度振幅 $V_{a \max }$ は $x_{\mathrm{c}}=817 \mathrm{~mm}$ における速度振幅 $V_{a}$ を式(2)に代入して求めた。

Fig. 13， 14 は共鳴管の長さ $L$ を各々 $1,130 \mathrm{~mm}, 860$ $\mathrm{mm}$ に変えることで, 理論発生周波数を $f_{\mathrm{TH}}=75 \mathrm{~Hz}, 100$ $\mathrm{Hz}$ に変えて, 音波発生機を単独あるいは開口端結合し て動作させた場合の熱入力に対する最大圧力振幅 $P_{a \max }$ および最大速度振幅 $V_{a \max }$ の変化を示す. なお, 実際に 発生する周波数は $f_{\mathrm{TH}}=100 \mathrm{~Hz}$ で $f=110 \mathrm{~Hz}$ であり, $f_{\mathrm{TH}}=75$ $\mathrm{Hz}$ で $f=80 \mathrm{~Hz}$ であった. いずれの場合も $f_{\mathrm{TH}}=100 \mathrm{~Hz}$ の 圧力および速度振幅が $75 \mathrm{~Hz}$ に比べて大きく，さらに発 生周波数の変化にかかわらず, 単独動作に比べ開口端 結合機の方が $P_{a \max }, V_{a \max }$ 共に大きいことがわかる.ま た, 音波による熱輸送量も $100 \mathrm{~Hz}$ のほうが多いことを 別途確認している.

Fig. 15(a)は各熱入力における理論発生周波数 $f_{\mathrm{TH}}$ の違 いによる音響の強さの最大值 $1 / 4 P_{a \max } V_{a \max }$ を, また, Fig. 15(b)は $P_{a \max }{ }^{2} /(4 \rho c)$ の変化を示す.

熱入力の増加に伴って音響の強さは増加している. さらに単独動作の場合, 各周波数における $1 / 4 P_{a \max } V_{a \max }$ と $P_{a \max }{ }^{2} /(4 \rho c)$ はほぼ等しい値を示すが, 開口端結合機 では $1 / 4 P_{a \max } V_{a \max }$ が $P_{a \max }{ }^{2} /(4 \rho c)$ を大きく上回ってい る.これは Fig. 3，4 に見られるように単独動作の場合 には, 圧力, 速度の両波形が正弦波形であるのに対し て, 開口端結合機では, 圧力, 速度波形が正弦波形よ り大きく異なっていることに起因する．その原因につ いては現在解析を進めているところであり，ここでは 言及しない. しかし，Fig. 13 から Fig. 15 に示すいずれ の場合でも, 単独動作および開口端結合機において $f_{\mathrm{TH}}=$ $100 \mathrm{~Hz}$ の結果が $75 \mathrm{~Hz}$ の結果を上回っていることから, 本研究に採用している形式の音波発生機では最適な理 論発生周波数 $f_{\mathrm{op}}$ が $100 \mathrm{~Hz}$ であることがわかる.

\section{4. 結言}

ループ型音波発生機を新しく開発し, 性能を確認し た. また, 音波発生機の性能に及ぼす発生音波周波数 の影響について調べ, 得られた主な結果は以下の通り である

（1）音波発生機を単独および他の結合で動作させた 場合に比ベ, ループ型音波発生機の圧力, 速度振
幅，音響の強さならびに音波による熱輸送量が大 幅に増大した。

（2）複数の音波発生機を開口端あるいはループ型に 結合して動作させると, 結合部に近付くにつれて, 特異な現象が生じ, 圧力変動の周波数が速度変動 の 2 倍となり, 波形は正弦波状を呈する.

（3）本研究に採用した形式の音波発生機では, 理論 発生音波周波数が $100 \mathrm{~Hz}$ の場合に性能が良いこと が分かった.

本研究を始めるにあたり, 有益な助言と暖かい励ま しをいただいた前日本大学教授 是永定美博士ならび に実験遂行に協力頂いた日本大学大学院生 瀬尾宜時 氏に感謝する。

\section{参 考 文 献}

1) G.W.Swift: Thermoacoustic engines, J. Acoust. Soc. Am. 84-4 (1988) 1145

2) S.L.Garrett and T.J. Hofler: Thermoacoustic Refrigeration ; 熱音響冷凍（信太茂訳）, 冷凍 68-788 (1993) 26

3) 飛原英治 : 共鳴管型冷凍機, 伝熱研究 36-142 (1997) 57

4) 西部ガスニュージアムリーフレット. ガスオルガ ン 37

5) 是永定美, 畠沢政保, 畑中 大, 中川麻希子: 熱 音響音波発生機の流れとその応用（熱音響発電）， 日本機械学会論文集 66-646B (2000) 106

6) 森田浩之, 香沢政保, 是永定美: 熱音響冷凍機の 特性（周波数および強制冷却の影響）,日本機械 学会第 3 回スターリングサイクルシンポジウム 99-26 (1999) 145

7) 野中健太郎, 瀬尾宜時, 畠沢政保, 是永定美 : 突 き合わせ型熱音響音波発生機と冷凍機の性能. ibid. 137

8) 畠沢政保, 是永定美, 野中健太郎, 瀬尾宜時 : ル 一プ型熱音響音波発生機の特性. 日本機械学会第 4 回スターリングサイクルシンポジウム 00-15 (2000) 107

9）機械工学便覧, 基礎編, 応用編. 日本機械学会編. 丸善 (1993-3) A3-58

10) A.P.Dowling and J.E.Williams Ffowcs: Sound and sources of sound. Ellis Horwood Publishers (1983) 23

11）是永定美, 畠沢政保, 熱音響音波発生機内の流 れ, 日本機械学会講演論文集 97-1(III) (1997) 13 